\title{
Occupational Therapy and the Use of Technology on Older Adult Fall Prevention: A Scoping Review
}

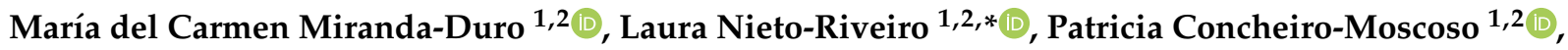

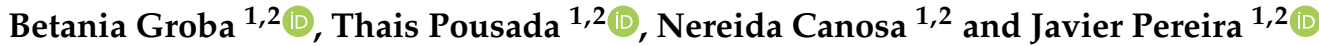 \\ 1 CITIC (Centre for Information and Communications Technology Research), TALIONIS Group, \\ Elviña Campus, University of A Coruna, 15071 A Coruña, Spain; carmen.miranda@udc.es (M.d.C.M.-D.); \\ patricia.concheiro@udc.es (P.C.-M.); b.groba@udc.es (B.G.); thais.pousada.garcia@udc.es (T.P.); \\ nereida.canosa@udc.es (N.C.); javier.pereira@udc.es (J.P.) \\ 2 Faculty of Health Sciences, Oza Campus, University of A Coruna, 15071 A Coruña, Spain \\ * Correspondence: laura.nieto@udc.es; Tel.: +34-881015870
}

check for updates

Citation: Miranda-Duro, M.d.C.; Nieto-Riveiro, L.; Concheiro-Moscoso, P.; Groba, B.; Pousada, T.; Canosa, N.; Pereira, J. Occupational Therapy and the Use of Technology on Older Adult Fall Prevention: A Scoping Review. Int. J. Environ. Res. Public Health 2021, 18, 702. https://doi.org/10.3390/ ijerph18020702

Received: 12 November 2020 Accepted: 12 January 2021 Published: 15 January 2021

Publisher's Note: MDPI stays neutral with regard to jurisdictional clai$\mathrm{ms}$ in published maps and institutional affiliations.

Copyright: (C) 2021 by the authors. Licensee MDPI, Basel, Switzerland. This article is an open access article distributed under the terms and conditions of the Creative Commons Attribution (CC BY) license (https:// creativecommons.org/licenses/by/ $4.0 /)$.

\begin{abstract}
Introduction: Falls are the second leading cause of accidental or non-intentional deaths worldwide and are the most common problem as people age. The primary purpose of addressing falls is to detect, prevent, treat, and reduce their incidence and consequences. Previous studies identified that multifactorial programs, an interprofessional team, and assistive technology are required to address falls in older adults effectively. Accordingly, the research question is as follows: what are the scope, type of studies, and approaches and strategies to fall risk using technology in the existing occupational therapy literature regarding interventions to address the effects of falls in older adults on daily living? Methods: This scoping review was carried out in January 2020 through Biblioteca Virtual de Salud España, C.I.N.A.H.L., Cochrane Plus, OTSeeker, PubMed, Scopus, and Web of Science. Results: Twelve papers were included. We analyzed the year and journal of publication, authors' affiliation, and design of the study, and thematic categories. There were three themes: participants' characteristics, type of intervention, and fall approach and type of technology used. Discussion and Conclusions: The literature obtained is scarce. It is considered to still be an emerging theme, especially when considering the use of technology for occupational therapy.
\end{abstract}

Keywords: older adults; falls; occupation; occupational therapy; scoping review; smart home technology; telehealth; exergames; 3D-application tool

\section{Introduction}

The progressive aging of the population is a well-documented and projected theme of the 21st century, particularly in Europe and Japan [1-3]. Certain health conditions associated with the aging process lead to geriatric syndromes, including falls [4]. Current and past scientific evidence has identified falls as the second leading cause of accidental or non-intentional deaths worldwide and the most common and severe problem as people age [5-11]. Studies have shown that thirty percent of older adults suffer a fall annually, increasing to fifty percent for people aged eighty years and over, and this one of the primary causes of their hospitalization [5-11]. As people get older, they are more likely to fall. A recent study by Burton and colleagues [12] showed that the prevalence of falls has not changed in the last ten years.

Thus, the primary purpose of addressing falls, identified as a public health challenge, is to detect, prevent, treat, and reduce their incidence and consequences. There is a range of consequences from falls including a reduction in quality of life and increased socioeconomic costs. The consequences on quality of life can include decreased functional mobility, a decreased independence level, social restrictions, depression, loneliness, fear of falling and repeated falls [13-19]. 
Several factors can produce falls, and it is relevant to know these to aid in the detection process. According to the World Health Organization (WHO), intrinsic fall factors include factors mainly related to the aging process that affects the person. They also include factors that increased the risk of falls as living alone, taking some medicines (i.e., benzodiazepines) and having some medical conditions (i.e., cardiovascular diseases), impaired mobility and gait, sedentary behavior, fear of falling, nutritional deficiencies, impaired cognition, visual impairments, and foot problems [16]. On the other hand, extrinsic factors occur because older people often have problems with slipping or tripping, lack of good balance, or correction mechanisms to prevent falling. These factors include environmental hazards, unsuitable footwear and clothing, and inappropriate walking or assistive devices [16]. Fear of falling is a syndrome closely related to falls that can produce a fall $[16,20]$. Moreover, some studies have shown that around one-third of older adults develop a fear of falling after a fall $[20,21]$.

Fall prevention is focused on injuries or complications that occur because of falling [12,22]. Numerous studies [23] have demonstrated that many falls can be prevented through adequate assessment and intervention. Some of the most common and effective interventions include [23] gait stabilizing footwear, vitamin D, dietary supplements, medication adaptation, multiple interventions, multifactorial interventions, assistive device training, cognitive monitoring and intervention, environmental modification, and family and caregiver training [24-29].

Different authors have also suggested that multifactorial programs are useful for preventing and reducing falls because of the complexity in the types of falls [30]. According to the World Health Organization (WHO), the risk of falls increases when multiple risk factors are present [16]. These multifactorial programs [30] involve a combination of exercise (focus on strength, balance and mobility), and other options such as individualized and comprehensive fall risk assessment about the person and, their environment and education on fall prevention. The GeriaTIC project is an example of using multifactorial interventions for fall prevention [31]. A study by Close and colleagues highlighted that an interprofessional approach to this high-risk population can significantly decrease the risk of further falls and limit functional impairment [32].

The effectiveness of these multifactorial programs is also based on the need to have an interprofessional team for fall prevention and treatment and geriatric approaches [33]. This includes a physician, a neurologist, a nurse, a psychiatrist, a physical therapist, and an occupational therapist. The latter is part of the non-pharmacological intervention [34,35]. Elliot and colleagues [36], in a systematic review, classified occupational therapy interventions on older adults' falls into three types of intervention that are shown in Table 1.

Table 1. Summary of occupational therapy interventions for falls in older adults.

\begin{tabular}{|c|c|}
\hline & $\begin{array}{l}\text { Summary of Occupational Therapy Interventions for Falls } \\
\text { in Older Adults }\end{array}$ \\
\hline \multirow{4}{*}{$\begin{array}{l}\text { Single component } \\
\text { (includes only one of the } \\
\text { following components) }\end{array}$} & Exercise \\
\hline & Home safety assessment \\
\hline & Education about falls' prevention \\
\hline & Example: Lifestyle Integrated Functional Exercise study [37] \\
\hline \multirow{5}{*}{$\begin{array}{l}\text { Multicomponent intervention } \\
\text { (includes exercise and one of the } \\
\text { following options) }\end{array}$} & 1st option: educational components as: \\
\hline & Feet or footwear risk \\
\hline & Energy conservation strategies \\
\hline & Safe assistive device use, home modification \\
\hline & Fall recovery \\
\hline
\end{tabular}


Table 1. Cont.

\begin{tabular}{|c|c|}
\hline & $\begin{array}{l}\text { Summary of Occupational Therapy Interventions for Falls } \\
\text { in Older Adults }\end{array}$ \\
\hline & Medication routines \\
\hline & Nutrition and hydration \\
\hline & Relaxation stress management \\
\hline & $\begin{array}{l}\text { 2nd option: home modification with other fall prevention } \\
\text { intervention }\end{array}$ \\
\hline & $\begin{array}{l}\text { Example: Minimally Supervised Multimodal Exercise to } \\
\text { Reduce Falls Risk in Economically and Educationally } \\
\text { Disadvantaged Older Adults [38] }\end{array}$ \\
\hline \multirow{6}{*}{$\begin{array}{l}\text { Multifactorial intervention } \\
\text { (include the complex } \\
\text { assessment of different } \\
\text { components) }\end{array}$} & Fall risk \\
\hline & Environment, education, and group activities \\
\hline & Activities of daily living \\
\hline & Assistive devices \\
\hline & Self-efficacy or fear of falling \\
\hline & $\begin{array}{l}\text { Example: A single home visit by an occupational therapist } \\
\text { reduces the risk of falling after hip fracture in elderly women: } \\
\text { A quasi-randomized controlled trial [39] }\end{array}$ \\
\hline \multirow{3}{*}{$\begin{array}{c}\text { Population-based fall } \\
\text { prevention } \\
\text { (includes strategies implemented } \\
\text { across whole communities, two } \\
\text { different types) }\end{array}$} & Existing effective population-based fall prevention programs \\
\hline & Other population-based multicomponent interventions \\
\hline & $\begin{array}{l}\text { Example: Stepping On -Translating a Fall Prevention } \\
\text { Intervention Into Practice: A Randomized Community Trial [40] }\end{array}$ \\
\hline
\end{tabular}

In addition to multifactorial programs and the interprofessional team, more emphasis is being placed on technology use. Technology has been integrated into some of the interventions for, or approaches to, fall reduction [18]. Assistive technology has been used to enable and promote inclusion and participation, maintain or improve functioning and independence, and promote well-being and active living [41-43].

According to the $\mathrm{WHO}$ [41], around the world, there are one billion people who require assistive products today. More than two billion people worldwide are expected to need at least one assistive product by 2030 [41]. Some examples of using assistive technology in older adults' falls interventions may include, video monitoring, health monitoring, electronic sensors, and equipment such as fall detectors, door monitors, bed alerts, pressure mats, and smoke and heat alarms, according to Miskelly and colleagues [42].

Also, remembering that exercise is the most common approach to falls, previous European projects such as the iStoppFalls [44], Farseeing [45] and Prevent IT [46] project were focused on using technology to improve older adults' physical functioning.

Accordingly, this study's primary goal is to explore the scope of occupational therapy literature regarding interventions to address the effects of falls in older adults on daily living with technology. Specifically, we intend to:

- Describe the types of studies on this topic and where they are usually published;

- Describe proposed occupational therapy approaches and strategies to fall risk using technology.

\section{Materials and Methods}

The authors conducted a scoping review in January 2020. The research questions that we aimed to answer were the following: what are the scope, type of studies, and approaches and strategies to fall risk using technology in the existing occupational therapy literature regarding interventions to address the effects of falls in older adults on daily living? Two approaches guided the present scoping review. On the one hand, the Arksey 
and O'Malley [47] five-stage framework was used, which includes stage 1 establishment of the research question; stage 2 identification of pertinent studies and choice of studies, stage 3 study selection as explained in Figure 1; and, as shown in the Results section, the stage 4 charting the data and stage 5 mapping the data and collating, summarizing, and reporting the findings. On the other hand, this scoping review also follows the Preferred Reporting Items for Systematic reviews and Meta-Analyses extension for Scoping Reviews (PRISMA-ScR) (see Table S1 [48]. In accordance with the aim of a scoping review, a quality appraisal is not required, as opposed to Systematic reviews and Meta-Analyses [49].

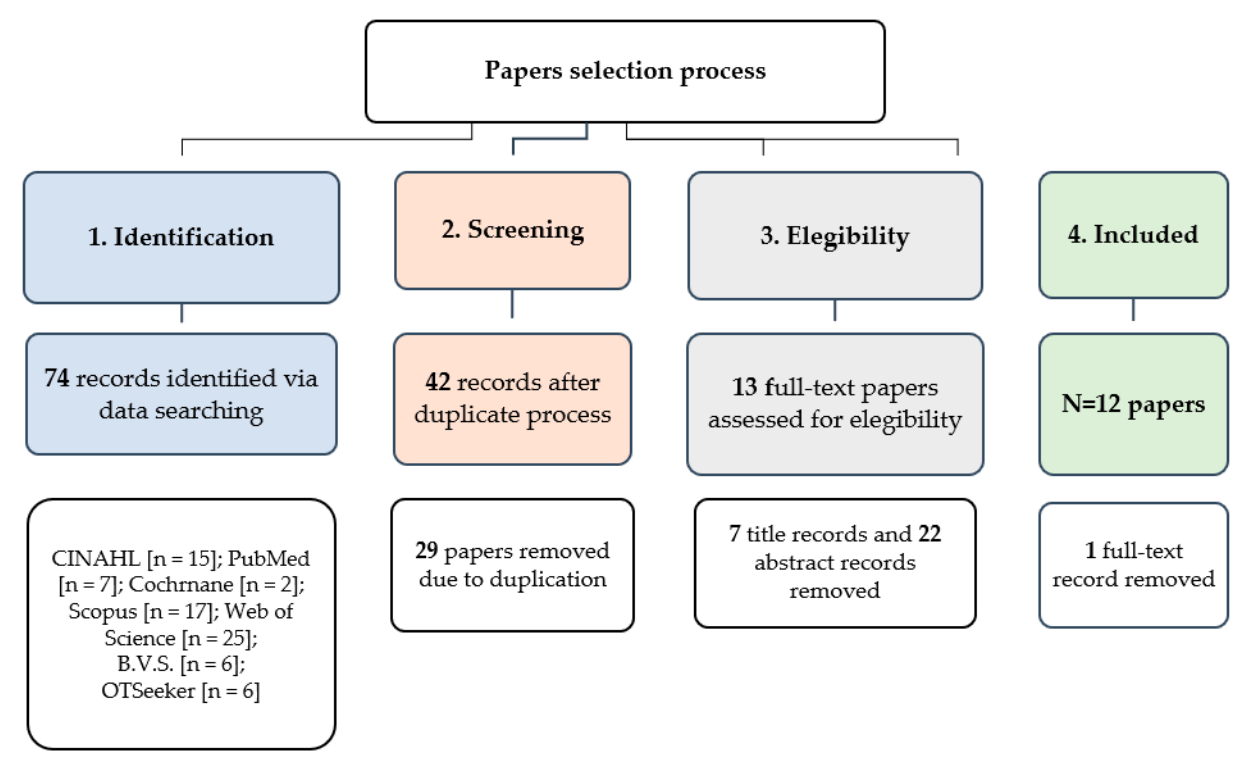

Figure 1. Flow diagram of the Scoping Review process.

\subsection{Sources and Search Strategy}

The search was focused on seven electronic databases (see supplementary Table S2 in the supplementary materials), specifically on health sciences and occupational therapy: Biblioteca Virtual de Salud España [50], C.I.N.A.H.L. [51], Cochrane Plus [52], OTSeeker [53], PubMed $^{\circledR}$ [54], Scopus [55], and Web of Science [56].

The criteria used were flexible due to this being a current topic. The eligibility criteria were papers written in English, Portuguese, and/or Spanish; there was no limit on the year of publication; studies could only involve humans; and all types of documents (i.e., original articles, reviews, conference papers) were considered. Individual search strategies (see supplementary Table S2 in the supplementary materials) were used for each database using a combination of the operators "AND" and "OR," jointly with the criteria defined and the following descriptors:

- occupational therapy, ergotherapy;

- falls, accidental falls;

- aged, geriatrics, gerontology, older adult, older person, elder person, older people, elderly, elderly people, veteran, retired, senior;

- technology, technologies, wearable electronic devices, wearables, computers, digital games.

\subsection{Study Selection and Data Extraction}

After searching, in accordance with the PRISMA-ScR guidelines [48], the first step was to identify all of the records, which were imported into the bibliographic manager Mendeley [57]. The second step was screening, whereby duplications were removed through Mendeley [57]. In the eligibility step, the results were assessed by title, abstract, or full text, following the eligibility criteria defined and in accordance with the topic of interest-occupational therapy interventions based on technology to address falls in older 
adults (see supplementary Table S3 on supplementary materials). Thus, the studies had to involve falls, the older adult population, an occupational therapy perspective, and the use of technology. In total, 12 papers met the defined criteria. See the details of these processes in the Figure 1 in the Section 3.

\subsection{Data Analysis}

Data were compiled in Microsoft Excel ${ }^{\circledR}$ (Redmond, DC, USA) for validation, coding, and analysis. Bibliometric and thematic variables were used to analyze the characteristics of the studies. Frequencies and/or percentages were used to show the following bibliometric characteristics: year of publication, authors' affiliation, journal of publication, and type and design of the study. A thematic analysis was also conducted as a "method for identifying, analyzing, and reporting patterns (themes) within data" ([58], p. 79). According to Braun and Clarke "a theme captures something important about the data in relation to the research question, and represents some level of patterned response or meaning within the data set" ([58], p. 80). For this reason, the authors identified the following three themes: a description of the type of participants in study, types of intervention and approach to falls, and type of technology used.

\section{Results}

A total of 12 papers met the eligibility criteria and were included in the present Scoping Review. Figure 1 gives an explanation of the selection process for choosing these papers. Tables 2 and 3 summarizes the papers.

\subsection{Bibliometric Characteristics}

In total, we screened 74 documents, with 12 studies meeting the eligibility criteria (see Figure 1). The selected literature was published between 2012 and 2020. The first study to report the use of technology in an occupational therapy falls approach was published in 2012 [58].

The studies were conducted in the USA $(n=4)$ [58-61]; Europe $(n=6)$ [62-67], specifically in Scotland $(n=1)$ [62], Sweden $(n=1)$ [63], the UK $(n=3)$ [64,66,67], and Belgium $(n=1)$ [65]; and other countries such as Tunisia $(n=1)$ [68] and Australia $(n=1)$ [69].

The journals in which the articles were published were mainly those focusing on occupational therapy $(n=6)$ [58-62], particularly for the first publications of studies on the topic, and informatics and technological journals $(n=6)$ [64-69], which contained more of the recent studies.

The types of study were reviews-a systematic review $(n=1)$ [58] and a critical review $(n=1)[59]$ and original articles $(n=10)[59-61,67,68]$. Within the original articles, there were different research designs. Quantitative approaches were used, including a descriptive study $(n=1)$ [66], a case study $(n=2)[60,61]$, and an experimental study $(n=1)$ [68]. The qualitative approaches used were qualitative research $(n=2)[63,69]$ and a mixed-methods study $(n=2)[65,66]$. 
Table 2. Summary of data extracted from the 12 selected studies.

\begin{tabular}{|c|c|c|c|c|c|c|}
\hline $\begin{array}{l}\text { Author(s), Year, } \\
\text { [Reference] }\end{array}$ & Authors' Affiliation & $\begin{array}{l}\text { Journal of } \\
\text { Publication }\end{array}$ & Type of Study and Purpose & $\begin{array}{l}\text { Sample Characteristics (Size, } \\
\text { Age, \% of Female, Setting, } \\
\text { and Others) }\end{array}$ & Technology Used & Main Findings \\
\hline \multirow{4}{*}{$\begin{array}{l}\text { Chase, C.A.; Mann, K.; } \\
\text { Wasek, S. and Arberman, } \\
\text { M. } 2012 \text { [58] }\end{array}$} & \multirow{4}{*}{$\begin{array}{l}\text { Western Michigan } \\
\text { University; } \\
\text { Rehabilitation } \\
\text { Hospital of Indiana; } \\
\text { Ingham County } \\
\text { Medical Center and } \\
\text { Rehabilitation; } \\
\text { University of Buffalo. } \\
\text { U.S.A. }\end{array}$} & \multirow{4}{*}{ Am. J. Occup. Ther. } & \multirow{4}{*}{$\begin{array}{l}\text { This systematic review aims to } \\
\text { synthesize existing literature about } \\
\text { the effect of home modification as } \\
\text { both a separate intervention and a } \\
\text { component of several fall } \\
\text { prevention programs. }\end{array}$} & $\begin{array}{l}n=33 \text { studies, including a } \\
\text { total of } 31 \text { randomized } \\
\text { controlled trials }\end{array}$ & \multirow{4}{*}{$\begin{array}{l}\text { Commercially available smart } \\
\text { home technology: operate lights, } \\
\text { appliances, door, and windows } \\
\text { for frail older adults living } \\
\text { alone. }\end{array}$} & \multirow{4}{*}{$\begin{array}{l}\text { The results contribute to } \\
\text { evidence-based practice for } \\
\text { occupational therapy } \\
\text { practitioners working with } \\
\text { older adults in } \\
\text { community-based settings and } \\
\text { reinforce the importance of the } \\
\text { role of occupational therapy in } \\
\text { the home and community. }\end{array}$} \\
\hline & & & & $\begin{array}{l}\text { Age }=\text { is focused on older } \\
\text { adults (not specify ages) }\end{array}$ & & \\
\hline & & & & $\begin{array}{l}\text { Setting = community-dwelling } \\
\text { older adults }\end{array}$ & & \\
\hline & & & & $\begin{array}{l}\text { Female }=\text { Number of females } \\
\text { not specified }\end{array}$ & & \\
\hline \multirow{4}{*}{$\begin{array}{l}\text { Stewart, L. and } \\
\text { McKinstry, B. } 2012 \text { [62] }\end{array}$} & \multirow{4}{*}{$\begin{array}{l}\text { Astley Ainslie } \\
\text { Hospital; Edinburgh } \\
\text { University, Edinburgh }\end{array}$} & \multirow{4}{*}{ Br. J. Occup. Ther. } & \multirow{4}{*}{$\begin{array}{l}\text { This critical review aimed to } \\
\text { evaluate the association between } \\
\text { older people's fear of falling and } \\
\text { the use of telecare and whether } \\
\text { telecare could reduce this fear. }\end{array}$} & $\begin{array}{l}n=10 \text { studies, including } \\
\text { randomized controlled trials, a } \\
\text { cohort study, two qualitative } \\
\text { studies, a case study, and } \\
\text { surveys }\end{array}$ & \multirow{4}{*}{$\begin{array}{l}\text { Telecare: this is understood as } \\
\text { the remote or enhanced delivery } \\
\text { of health and social services to } \\
\text { people in their own homes } \\
\text { using telecommunications and } \\
\text { computerized systems. }\end{array}$} & \multirow{4}{*}{$\begin{array}{l}\text { Telecare's contribution to } \\
\text { supporting an aging } \\
\text { population at home for longer } \\
\text { is becoming increasingly } \\
\text { recognized by health and } \\
\text { social care services worldwide. } \\
\text { However, this critical review } \\
\text { identified that few studies are } \\
\text { investigating older people's } \\
\text { views and the use of telecare } \\
\text { in the domain of occupational } \\
\text { therapy. }\end{array}$} \\
\hline & & & & $\begin{array}{l}\text { Age }=\text { older adults over } \\
60 \text { years old }\end{array}$ & & \\
\hline & & & & $\begin{array}{l}\text { Setting = older adults from } \\
\text { public-assisted housing, day } \\
\text { centers, and community living }\end{array}$ & & \\
\hline & & & & $\begin{array}{l}\text { Female = Number of females } \\
\text { not specified }\end{array}$ & & \\
\hline \multirow{4}{*}{$\begin{array}{l}\text { Horowitz, B.; Nochajski, } \\
\text { S.M. and Schweitzer, H.A. } \\
2013 \text { [59] }\end{array}$} & \multirow{4}{*}{$\begin{array}{l}\text { York College- CUNY; } \\
\text { University of Buffalo; } \\
\text { State University of } \\
\text { New York. U.S.A. }\end{array}$} & \multirow{4}{*}{$\begin{array}{l}\text { Occup. Ther. Health } \\
\text { Care }\end{array}$} & \multirow{4}{*}{$\begin{array}{l}\text { This case study focused on the } \\
\text { development and pilot-testing of } \\
\text { the Home Safety Self-Assessment } \\
\text { Tool (H.S.S.A.T.), a new home } \\
\text { assessment tool designed for use by } \\
\text { older adults to promote home } \\
\text { safety and aging. }\end{array}$} & $n=28$ older adults & \multirow{4}{*}{$\begin{array}{l}\text { Videos: developed with } \\
\text { instructions to install home } \\
\text { modifications to prevent falls. } \\
\text { Several tools were included to } \\
\text { analyze the risks associated with } \\
\text { older adults' homes in the } \\
\text { project. }\end{array}$} & \multirow{4}{*}{$\begin{array}{l}\text { The results suggest the tool } \\
\text { may assist older adults in } \\
\text { identifying environmental } \\
\text { factors related to falls and } \\
\text { facilitate their ability to age in } \\
\text { place. }\end{array}$} \\
\hline & & & & & & \\
\hline & & & & Female $=68 \%$ & & \\
\hline & & & & Setting = community dwelling & & \\
\hline
\end{tabular}


Table 2. Cont.

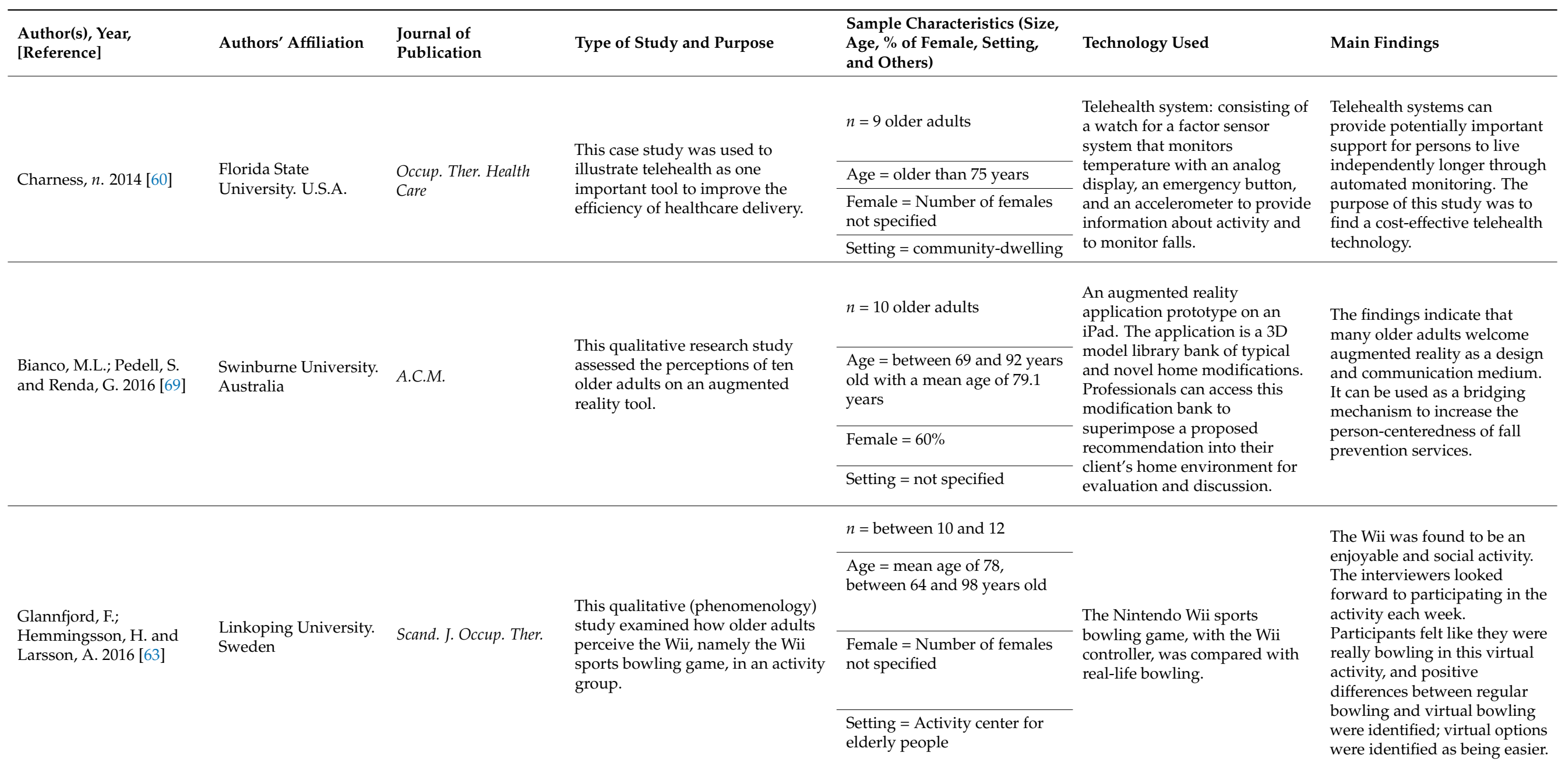


Table 2. Cont.

\begin{tabular}{|c|c|c|c|c|c|c|}
\hline $\begin{array}{l}\text { Author(s), Year, } \\
\text { [Reference] }\end{array}$ & Authors' Affiliation & $\begin{array}{l}\text { Journal of } \\
\text { Publication }\end{array}$ & Type of Study and Purpose & $\begin{array}{l}\text { Sample Characteristics (Size, } \\
\text { Age, \% of Female, Setting, } \\
\text { and Others) }\end{array}$ & Technology Used & Main Findings \\
\hline \multirow{4}{*}{$\begin{array}{l}\text { Hamm, J.; Money, G.A. } \\
2017 \text { [64] }\end{array}$} & \multirow{4}{*}{$\begin{array}{l}\text { Brunel University, } \\
\text { London South Bank } \\
\text { University. U.K. }\end{array}$} & \multirow{4}{*}{ Health Informatics J. } & \multirow{4}{*}{$\begin{array}{l}\text { This mixed-study explored } \\
\text { occupational therapists' perceptions } \\
\text { of an early-stage, three-dimensional } \\
\text { measurement aid prototype, which } \\
\text { provides enhanced assistive } \\
\text { equipment provision process } \\
\text { guidance to clinicians. }\end{array}$} & $n=10$ occupational therapists & \multirow{4}{*}{$\begin{array}{l}\text { A 3D measurement aid } \\
\text { prototype (3D-MAP) } \\
\text { application, using 3D } \\
\text { visualization technology was } \\
\text { deployed on a tablet, mobile } \\
\text { phone, or laptop. This was } \\
\text { based on the five most } \\
\text { commonly measured items with } \\
\text { the Assistive Equipment } \\
\text { Provision Process tool (bed, } \\
\text { bath, toilet, chair, and stairs). }\end{array}$} & \multirow{4}{*}{$\begin{array}{l}\text { The results show that } \\
\text { occupational therapists } \\
\text { considered that the 3D-MAP } \\
\text { application could effectively } \\
\text { augment existing 2D diagrams } \\
\text { and deliver numerous benefits. }\end{array}$} \\
\hline & & & & Female $=100 \%$ & & \\
\hline & & & & $\begin{array}{l}\text { A ten pounds voucher was } \\
\text { offered } \\
2 \text { to } 31 \text { years of experience. }\end{array}$ & & \\
\hline & & & & $\begin{array}{l}\text { The occupational therapists' } \\
\text { experience was in adults, } \\
\text { social services, surgical } \\
\text { rehabilitation, neurology, } \\
\text { re-ablemen, and social } \\
\text { services. }\end{array}$ & & \\
\hline \multirow{10}{*}{$\begin{array}{l}\text { Lemmens, R.; Gielen, C. } \\
\text { and Spooren, A. } 2017 \text { [65] }\end{array}$} & \multirow{10}{*}{$\begin{array}{l}\text { P.X.L. University } \\
\text { College. Belgium }\end{array}$} & \multirow{10}{*}{$\begin{array}{l}\text { Stud. Health. Technol. } \\
\text { Inform. }\end{array}$} & \multirow{10}{*}{$\begin{array}{l}\text { This was a qualitative study about } \\
\text { developing a screening tool to } \\
\text { enable occupational therapists to } \\
\text { assess people's home environments } \\
\text { to facilitate independent living. }\end{array}$} & 1st phase: & \multirow{10}{*}{$\begin{array}{l}\text { The Obstacle tool is a digitalized } \\
\text { version using the mind maps } \\
\text { and the paper version results for } \\
\text { tablets. It has a version that can } \\
\text { be used by health professionals } \\
\text { or informal caregivers too. The } \\
\text { digital version includes (1) the } \\
\text { possibility of structuring the } \\
\text { screening by adding the rooms } \\
\text { in the order of preference for } \\
\text { occupational therapists, (2) } \\
\text { registration of problems/scores, } \\
\text { (3) the addition of photos to the } \\
\text { screening, (4) a better overview } \\
\text { than in the paper version, (5) the } \\
\text { option to store and save data } \\
\text { and make a back-up, and (6) } \\
\text { connection with the application } \\
\text { H-OPP (a digital coach for } \\
\text { occupational therapists). }\end{array}$} & \multirow{10}{*}{$\begin{array}{l}\text { The Obstacle tool was } \\
\text { developed and judged to be } \\
\text { very useful by occupational } \\
\text { therapists. It was highlighted } \\
\text { that the Obstacle is adapted } \\
\text { for use for persons with } \\
\text { dementia and a mini-obstacle } \\
\text { tool is under construction and } \\
\text { will be digitalized to be } \\
\text { available for clients and their } \\
\text { informal caregivers. The next } \\
\text { step is to make the tool } \\
\text { accessible to everybody. }\end{array}$} \\
\hline & & & & $\begin{array}{l}n=16 \text { older adults in their } \\
\text { homes }\end{array}$ & & \\
\hline & & & & Aged over 65 years old & & \\
\hline & & & & 2nd phase: & & \\
\hline & & & & $n=31$ older adults & & \\
\hline & & & & Aged over 65 years old & & \\
\hline & & & & 3rd phase: & & \\
\hline & & & & $\begin{array}{l}n=5 \text { older adults, } 5 \text { informal } \\
\text { caregivers, } 5 \text { professional } \\
\text { caregivers }\end{array}$ & & \\
\hline & & & & Setting = community-dwelling & & \\
\hline & & & & $\begin{array}{l}\text { The number of females was } \\
\text { not specified }\end{array}$ & & \\
\hline
\end{tabular}


Table 2. Cont.

\begin{tabular}{|c|c|c|c|c|c|c|}
\hline $\begin{array}{l}\text { Author(s), Year, } \\
\text { [Reference] }\end{array}$ & Authors' Affiliation & $\begin{array}{l}\text { Journal of } \\
\text { Publication }\end{array}$ & Type of Study and Purpose & $\begin{array}{l}\text { Sample Characteristics (Size, } \\
\text { Age, \% of Female, Setting, } \\
\text { and Others) }\end{array}$ & Technology Used & Main Findings \\
\hline \multirow{4}{*}{$\begin{array}{l}\text { Arthanat, S.; Wilcox, J. } \\
\text { and Macuch, M. } 2019 \text { [61] }\end{array}$} & \multirow{4}{*}{$\begin{array}{l}\text { The University of } \\
\text { Hampshire. U.S.A. }\end{array}$} & \multirow{4}{*}{ O.T.J.R. } & \multirow{4}{*}{$\begin{array}{l}\text { This descriptive study aimed to } \\
\text { determine the extent to which smart } \\
\text { home technology has been adopted } \\
\text { by older adults, what types of } \\
\text { smart home devices are being used, } \\
\text { the health factors related to the } \\
\text { adoption of this technology, and the } \\
\text { factors that contribute to smart } \\
\text { homeownership and readiness. }\end{array}$} & $n=445$ older adults & \multirow{4}{*}{$\begin{array}{l}\text { Smart Home Technology: sensor } \\
\text { networks to monitor and gather } \\
\text { information about the state of } \\
\text { the home and its residents, } \\
\text { mechanisms that allow } \\
\text { communication between devices } \\
\text { to enable automation and } \\
\text { remote access, and user } \\
\text { interfaces such as home } \\
\text { displays, personal computers, } \\
\text { tablets, and smartphones to } \\
\text { enable consumers to set } \\
\text { preferences/goals and receive } \\
\text { information and feedback. }\end{array}$} & \multirow{4}{*}{$\begin{array}{l}\text { The present study concluded } \\
\text { that adoption and interest in } \\
\text { smart home technology are } \\
\text { relatively low among older } \\
\text { adults. The levels of } \\
\text { ownership and readiness vary } \\
\text { vastly by technology, } \\
\text { demographic segments, } \\
\text { functional status, and home } \\
\text { safety. These aspects could be } \\
\text { taken into account by } \\
\text { occupational therapists. }\end{array}$} \\
\hline & & & & $\begin{array}{l}\text { Age }=\text { a mean age of } 70.7 \\
\text { between } 60 \text { and } 95 \text { years old }\end{array}$ & & \\
\hline & & & & Setting = community dwelling & & \\
\hline & & & & Female $=68 \%$ & & \\
\hline \multirow{4}{*}{$\begin{array}{l}\text { Hamm, J.; Money, A.G. } \\
\text { and Atwal, A. } 2019 \text { [66] }\end{array}$} & \multirow{4}{*}{$\begin{array}{l}\text { Brunel University, } \\
\text { London South Bank } \\
\text { University. U.K. }\end{array}$} & \multirow{4}{*}{ J. Biomed. Inform. } & \multirow{4}{*}{$\begin{array}{l}\text { This mixed-method study aimed to } \\
\text { present a 3D mobile application to } \\
\text { enable older adults to carry out } \\
\text { self-assessment measurement tasks } \\
\text { in accordance to two different } \\
\text { treatment conditions, using a 3D } \\
\text { guidetomeasure tool or a 2D } \\
\text { paper-based guide. }\end{array}$} & $n=37$ participants & \multirow{4}{*}{$\begin{array}{l}\text { The application 3D } \\
\text { guidetomeasure-3D was } \\
\text { developed by the Unity3D game } \\
\text { engine, which supports } \\
\text { multi-platform deployment, } \\
\text { including Android, IOS, } \\
\text { desktops, and Web. The unity3D } \\
\text { engine includes an avatar model, } \\
\text { 3D furniture models, and arrow } \\
\text { prompts of the application. }\end{array}$} & \multirow{4}{*}{$\begin{array}{l}\text { An empirical mixed-methods } \\
\text { assessment of the performance } \\
\text { of the guidetomeasure-3D } \\
\text { application revealed that, in } \\
\text { terms of accuracy, consistency, } \\
\text { task completion time, and } \\
\text { usability, significant } \\
\text { performance gains were } \\
\text { achieved over the art's current } \\
\text { state paper-based 2D } \\
\text { measurement guide } \\
\text { equivalent. }\end{array}$} \\
\hline & & & & $\begin{array}{l}\text { Age }=\text { mean age of } 68.5, \\
\text { between } 55 \text { and } 86 \text { years old } \\
(20 \text { retired, } 11 \text { employed, three } \\
\text { not specified) }\end{array}$ & & \\
\hline & & & & Female $=$ Not specified & & \\
\hline & & & & Setting $=$ Not specified & & \\
\hline
\end{tabular}


Table 2. Cont.

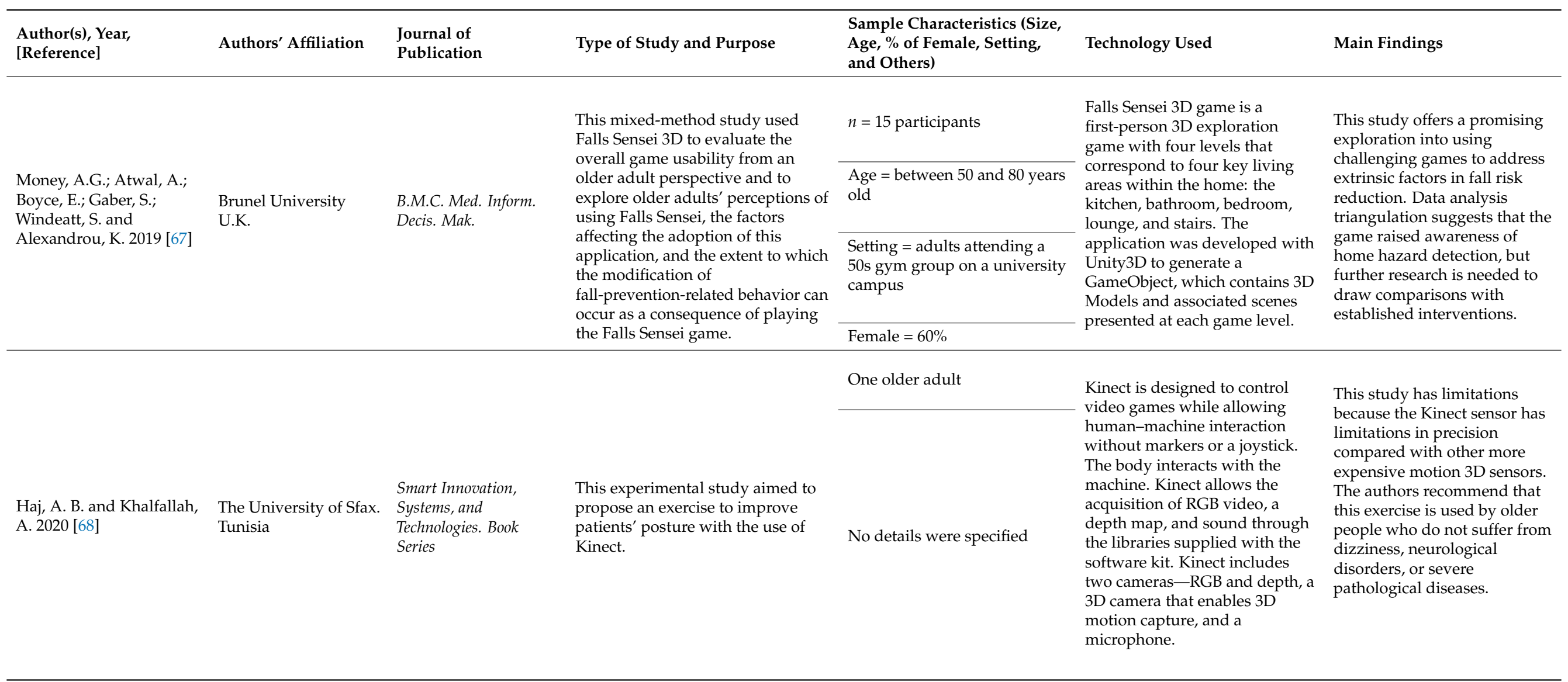




\subsection{Thematic Categories}

\subsubsection{A Description of the Type of Participants in Study}

This theme was about the types of participants included in the studies (i.e., older adult(s) or occupational therapist(s)), the age of the participants, the percentage of females in the sample, the environment in which the study was conducted (i.e., communitydwelling or an institution), and other interesting details mentioned.

The reviews included in this study did not provide some of the participants' characteristics (see Table 3 details of the participants). In a review by Chase and colleagues [58], a total of thirty-three studies were included, all randomized controlled trials, while in the review by Stewart and colleagues study [62], ten studies were included and these were different types of studies.

The original articles [59-61,63-65,67-69] included 614 older adults, 15 occupational therapists, and 5 informal caregivers. The samples size of the studies included $1(n=1)$ [68] to $445(n=1)$ older adults [61], $1(n=7)[59-61,63,66,67,69]$ to $10(n=1)$ types of occupational therapy [64], and $1(n=9)$ to $5(n=1)$ informal caregivers [65]. There was a large age range age of older adults from 50 years old $(n=1)$ [67] to a maximum of 98 years old $(n=1)$ [63]. These people were recruited from the community $(n=8)$ [59-61,65], an activity center for older adults $(n=1)$ [63], or people attending a gym group on a university campus $(n=1)$ [67]. Regarding the percentage of females, all studies included more females than males, with a percentage of females of between $60(n=2)[64,69]$ and $68 \%(n=2)[59,61]$. One hundred percent of the occupational therapists were female [64].

All participants volunteered to participate in the different studies, but in the study by Hamm and colleagues, the occupational therapists received a ten pound voucher [64].

\subsubsection{Type of Intervention and Approach to Falls}

This theme included the type of intervention if the study was about a specific risk factor related to falls (extrinsic, alien to the individual, or intrinsic, related to the person and the aging process) and the type of approach to falls (detection, prevention, or treatment).

Four types of intervention were identified: "home modifications" $(n=5)$ [59,64-66,69], "assistive technology" $(n=4)$ [58,60-62], "exercise" $(n=2)$ [63,68], and "educational" $(n=2)[59,67]$. We considered single-component interventions and focused on fall detection, prevention, and treatment. Interventions that focused on home modification addressed extrinsic factors such as bathroom modifications (i.e., bath, toilet, shower), appropriate chair height, and indications to include space to move, among others. Assistive technology interventions addressed extrinsic factors that can affect the safety of the person in the home. This included the use of telecare, emergency alarms, and fall detectors (i.e., pendant alarms). Exercise was used as a strategy to address intrinsic factors related to physical condition and the use of educational interventions in these studies was based on extrinsic factors, which consisted of the types of modification the person has to do to be safe at home.

\subsubsection{Type of Technology Used}

This theme was about the types of technology addressed in the studies. The technologies used in the studies were classified as software developments, telehealth, multimedia materials, and commercial and technological devices. Software developments $(n=5)$ included augmented reality applications [69], 3D measurement aid prototype applications [64,66], a digital version of the Obstacle Tool [61], and a Falls Sensei 3D game [67]. The use of telehealth was integrated into telecare to reduce the fear of falling [62], and the system was integrated into a watch to provide a factor sensor system to monitor temperature with an analog display, an emergency button, and an accelerometer [60]. The multimedia materials included different videos to identify environmental fall factors [59]. The commercial and technological devices included smart home technology to operate lights, appliances, doors, and windows [58], and these included the use of Kinect [68] and Nintendo Wii [63]. 
Table 3 shows the relationships between Section 3.2.2 (Type of intervention and approach to falls) and Section 3.2.3 (Type of technology used, and the compatibility of the technology used with the technological devices: Tablet, iPad, computer, laptop, Xbox, Nintendo Wii, and mobile phone).

Table 3. Relationships between Section 3.2.2. and Section 3.2.3.

\begin{tabular}{|c|c|c|c|c|}
\hline Types of Technology & Technology Used & Compatibility & Intervention & Falls Risk \\
\hline \multirow{4}{*}{ Software developments } & $\begin{array}{l}\text { Augmented reality } \\
\text { application }\end{array}$ & iPad & \multirow{4}{*}{ Home modifications } & \multirow{4}{*}{ Extrinsic factors } \\
\hline & $\begin{array}{l}\text { 3D measurement aid } \\
\text { prototype application }\end{array}$ & $\begin{array}{l}\text { Tablet, mobile phone, } \\
\text { or laptop }\end{array}$ & & \\
\hline & $\begin{array}{l}\text { Digital version of } \\
\text { Obstacle Tool }\end{array}$ & Tablet & & \\
\hline & Falls Sensei 3D game & Computer & & \\
\hline \multirow{3}{*}{ Telehealth } & Telehealth system & Not applied & \multirow{3}{*}{ Assistive technology } & \multirow{3}{*}{ Extrinsic factors } \\
\hline & Telecare & & & \\
\hline & Smart home technology & & & \\
\hline Multimedia materials & Videos & $\begin{array}{l}\text { Computer, laptop, } \\
\text { mobile phone or Tablet }\end{array}$ & Educational & Extrinsic factors \\
\hline $\begin{array}{l}\text { Commercial and } \\
\text { technological devices }\end{array}$ & $\begin{array}{l}\text { Kinect with Xbox and } \\
\text { Nintendo Wii }\end{array}$ & $\begin{array}{l}\text { Kinect with Xbox and } \\
\text { Nintendo Wii }\end{array}$ & Exercise & Intrinsic factors \\
\hline
\end{tabular}

\section{Discussion}

This study presents the first scoping review of occupational therapy interventions to address older adults' falls using technology. The objectives defined focused on exploring the literature about the topic to determine the type of studies conducted, where these studies have usually been published, and the approaches and strategies used to reduce fall risk by occupational therapists using technology.

The results show that this is an emerging area, which began to be researched in the year 2012 [58]. In a review by Chase and colleagues on home modification, only telecare was mentioned as a possible strategy by occupational therapists, but occupational therapists did not specifically develop that study. However, previous studies focused on the use of technology. For example, the iStoppFalls project focused on the use of exergames to reduce falls in older adults; this project was conducted from 2011 to 2014 to motivate and enhance the use of physical activity by community-dwelling adults aged more than sixty-five years by engaging with three purpose-built exergames to reduce falls $[43,70]$.

The present review shows a trend toward carrying out studies with a qualitative approach $[63,69]$ and mixed-methods studies $[65,66]$, reinforcing the idea that is important to understand the perceptions and opinions of the older adults or occupational therapists and other health professionals under study to find out about their experiences with using the technology. This type of research helps us to understand the acceptance or not of technology and to determine how to improve or adapt it to make it useful in older people's day-to-day lives [71].

Regarding the place of publication, similar numbers of studies have been carried out in the USA [58-61] and Europe [62-67], even though progressive aging of the population is more apparent in Europe, and considering that previous European projects such as Prevent IT, Farseeing, and iStoppFalls, which are an essential background to fall prevention and the use of technology, were developed in Europe [43-45].

Compared with other reviews about falls and occupational therapy [41,69], the present scoping review results are of a lower research quality, because it was not possible to find any controlled trials to demonstrate the effectiveness of the interventions developed alongside technology. The types of studies included descriptive studies [61], case studies [59,60], 
experimental studies [68], and qualitative studies [63,69], which are not considered to give a high level of evidence. Instead, some controlled trials were carried out in the field of falls and occupational therapy, for example, the one by Monaco and colleagues [39].

As for the participant sample sizes and characteristics, the samples used were relatively small, except for one case [61]. This is linked to the level of evidence mentioned above and the types of study used. The types of participant included older adults, occupational therapists, and/or informal caregivers.

Only one of the types of software developed, obstacle tool digitalization [65], was tested in older adults, occupational therapists, and informal caregivers. The aim was to make it accessible for everybody, which is an essential factor to keep in mind in software development, according to the accessible software development model [72], the philosophy of design for all [73], and the inclusive perspective of the occupational therapy [74], as this helps to break the digital divide, particularly among older adults [74].

The studies included an extensive range of ages from 50 [67] to 98 years old [63], although older persons are classified as those aged 65 or more years. This reflects the perspective of preventing falls in people nearing retirement and the importance of active, healthy aging throughout life $[75,76]$. The life expectancy in Europe and USA, the main places of publication, is approximately 82 years old [74]. Life expectancy at age sixty is higher in women than men [77], and as can be seen in the results, females made up the highest percentage of participants in the studies, with $60-68 \%$ of participants being older women $[67,69]$.

Regarding the type of intervention used to address falls in older adults through occupational therapy, only single-component interventions were used [36], even though different authors have suggested that multifactorial programs help to prevent and reduce falls because of their complexity [30]. None of the studies included an interprofessional team, despite its importance. The effectiveness of the multifactorial programs is also due to the use of an interprofessional team for fall prevention and treatment [33].

In terms of multifactorial programs [30], these involved exercise, as was done in two studies included in this review [63,68]; individualized and comprehensive fall risk assessment about the environment of an older adult, as done in a few studies mentioned in this review [59,64-66,69]; and education on fall prevention, as done in two studies $[60,68]$. Furthermore, any intervention includes occupational therapy home visits [78], which can be an essential aspect to include, especially in the cases of home modification [59,64-66,69] and assistive technology [58,60-62]. The studies that integrated aging in place focused on assistive technology and home modifications because these factors are widely acknowledged as being the primary and preferred interventions during ageing $[79,80]$. Understanding how older people's needs contribute to improving their quality of life, which is affected after a fall, is necessary [13-16,18,19].

A previous systematic review explored the cost-effectiveness of several occupational therapy interventions for older people, concluding that they are useful and cost-effective compared with standard care or other therapies [81]. In this way, socioeconomic impact is one of the consequences of falls [28]. However, the results were not focused on aspects related to socioeconomic impact.

Our results reinforce the idea that home modifications, assistive technology, and educational interventions can address extrinsic factors, particularly environmental factors, and exercise can address intrinsic factors. This is in accordance with previous studies about the use of occupational therapy interventions to address fall risk [24,82-85].

Although, as mentioned above, some examples of assistive technology used to prevent falls in older adults include video-monitoring, health monitoring, electronic sensors, and fall detectors [42] these were not included in the studies mentioned in this review. Moreover, regarding fall interventions globally, there is more focus on exercise options and an extensive range of technologies from virtual reality [86] to wearables [87] that were not included in these studies. Primarily, virtual reality interventions are used in occupational therapy, for example, in children [86]. 
As a result of this review, it is suggested that researchers in this field perform more studies that include the latest technology in the field of falls, so that more studies with a higher level of evidence exist. Interprofessional and multifactorial interventions should be integrated.

\section{Limitations}

The present scoping review has few limitations since all those publications related to the topic have been included; regarding the language were included articles in English, Spanish, and Portuguese; and regarding the type of study, any of them were included. The first limitation maybe not including other languages or other databases in the search process. However, we included databases of occupational therapy and socio-health care. Regarding the searches and the inclusion and exclusion of studies, it was carried out by one of the authors, which may be a limitation. In spite that the researcher used a structured process, some data may have been omitted or excluded. As future research, it would be important to integrate more researchers into this process.

\section{Conclusions}

Although falls have been identified as a public health challenge and the importance of technology in our lives is well known, the literature available on the prevention of falls in older adults using technology is scarce. It is considered to be an emerging area, especially when considering the use of technology in occupational therapy.

The studies in this area have mainly been conducted in the USA and Europe and have been published in occupational therapy and informatics journals. The target population is those over 50 years of age. The risk factors that have most frequently been evaluated and considered are extrinsic factors, particularly environmental factors. Interventions on occupational therapy using technology to address falls in older adults have been single component methods, including home modifications, assistive technology, educational intervention, and exercise. The technology used in the studies can be classified as software developments, telehealth, multimedia material, and commercial technological devices. Lastly, the authors conclude that the prevention of falls in older adults is an essential part of interventions against the risk of falls, and occupational therapy and the use of technology may contribute greatly to interprofessional fall prevention programs.

Supplementary Materials: The following are available online at https: / www.mdpi.com/1660-4 601/18/2/702/s1, Table S1: Preferred Reporting Items for Systematic reviews and Meta-Analyses extension for Scoping Reviews (PRISMA-ScR) Checklist. Table S2: Search strategies from each database, Table S3: Removed from eligibility criteria.

Author Contributions: The authors contributed to this research article in the following ways. Conceptualization: M.d.C.M.-D., L.N.-R., P.C.-M. and J.P.; methodology: M.d.C.M.-D., L.N.-R. and J.P.; formal analysis, M.d.C.M.-D., L.N.-R., P.C.-M. and J.P.; investigation M.d.C.M.-D., L.N.-R., P.C.M. and J.P.; writing-original, M.d.C.M.-D., P.C.-M.; writing-review and editing, B.G., L.N.-R., T.P., N.C., J.P.; visualization and supervision, all authors. All authors have read and agreed to the published version of the manuscript.

Funding: The authors disclosed the receipt of the following financial support for the research, authorship, and/or publication of this article: The research team will bear all the economic costs involved in the study, with the support of the CITIC, as Research Center accredited by Galician University System that is funded by "Consellería de Cultura, Educación e Universidades from Xunta de Galicia," which provided 80\% of funds through ERDF Funds, ERDF Operational Programme Galicia 2014-2020, and the remaining 20\% was provided by "Secretaría Xeral de Universidades [Grant ED431G 2019/01]. Moreover, P.C.-M. obtained a scholarship [Ref.ED481A-2019/069] and M.D.C.M.-D. [Ref.ED481A 2018/205] gained a scholarship to develop a Ph.D. In addition, this work is also supported in part by the Ministerio de Ciencia e Innovación $\mathrm{R}+\mathrm{D}+\mathrm{I}$ projects in the framework of the national programs of knowledge generation and scientific and technological strengthening of the R+D+I system and the challenges of society's-oriented R+D+I 2019 call (PID2019-104323RB-C33).

Institutional Review Board Statement: Not applicable. 
Informed Consent Statement: Not applicable.

Conflicts of Interest: The authors declare no conflict of interest.

\section{References}

1. Hewit, P.S. Depopulation and Ageing in Europe and Japan. Available online: http://globalag.igc.org/health/world/depopulationeuropejapan. htm (accessed on 4 November 2020).

2. European Commission. Meeting the Challenge of Europe's Aging Workforce. The Public Employment Service Response. 2011. Available online: https:/ / ec.europa.eu/info/index_en (accessed on 4 November 2020).

3. Daykin, C.; Stavrakis, C.; Bogataj, D.; Risku, I.; Van den Bosch, J.; Woodall, J.; Economou, M.; Papamichail, M.; Gatenby, P.; Marcelloni, R.; et al. Meeting the Challenge of Ageing in the EU. 2019. Available online: https://actuary.eu/ (accessed on 4 November 2020).

4. Inouye, S.K.; Studenski, S.; Tinetti, M.E.; Kuchel, G.A. Geriatric syndromes: Clinical, research, and policy implications of a core geriatric concept. J. Am. Geriatr. Soc. 2007, 55, 780-791. [CrossRef] [PubMed]

5. Masud, T.; Morris, R.O. Epidemiology of falls. Age Ageing 2001, 30, 3-7. [CrossRef] [PubMed]

6. Kannus, P.; Parkkari, J.; Niemi, S.; Palvanen, M. Fall-Induced Deaths Among Elderly People. Am. J. Public Health 2005, 95, 422-424. [CrossRef] [PubMed]

7. McCarter-Bayer, A.; Bayer, F.; Hall, K. Preventing falls in acute care: An innovative approach. J. Gerontol. Nurs. 2005, 31, 25-33. [CrossRef] [PubMed]

8. United Nations Population Fund. HelpAge International. Ageing in the Twenty-First Century: A Celebration and A Challenge. 2012. Available online: www.unfpa.org (accessed on 1 November 2020).

9. United Nations. World Population Ageing. 2015. Available online: https://www.un.org/ (accessed on 1 November 2020).

10. World Health Organization. Falls. 2018. Available online: https://www.who.int/news-room/fact-sheets/detail/falls (accessed on 1 November 2020).

11. United Kingdom Government. Falls: Applying All Our Health. Available online: https://www.gov.uk/government/ publications / falls-applying-all-our-health/falls-applying-all-our-health (accessed on 1 November 2020).

12. Burton, E.; Lewin, G.; O'Connell, H.; Hill, K. Falls prevention in community care: 10 years on. Clin. Interv. Aging 2018, 13, 261-269. [CrossRef]

13. Lachman, M.E.; Howland, J.; Tennstedt, S.; Jette, A.; Assmann, S.; Peterson, E.W. Fear of falling and activity restriction: The Survey of Activities and Fear of Falling in the Elderly (SAFE). J. Gerontol. Ser. B Psychol. Sci. Soc. Sci. 1998, 53, 43-50. [CrossRef]

14. Cumming, R.G.; Salkeld, G.; Thomas, M.; Szonyi, G. Prospective study of the impact of fear of falling on activities of daily living, SF-36 scores, and nursing home admission. J. Gerontol. Ser. A Biol. Sci. Med. Sci. 2000, 55, M299-M305. [CrossRef]

15. Yardley, L.; Smith, H. A prospective study of the relationship between feared consequences of falling and avoidance of activity in community-living older people. Gerontologist 2002, 42, 17-23. [CrossRef]

16. World Health Organization. What Are the Main Risk Factors for Falls amongst Older People and What Are The Most Effective Interventions to Prevent These Falls? 2004. Available online: http://www.euro.who.int/document/E82552.pdf (accessed on 1 November 2020).

17. Kerse, N.; Flicker, L.; Pfaff, J.J.; Draper, B.; Lautenschlager, N.T.; Sim, M.; Snowdon, J.; Almeida, O.P. Falls, depression and antidepressants in later life: A large primary care appraisal. PLoS ONE 2008, 3, e2423. [CrossRef]

18. Bailey, C.; Foran, T.G.; NIi Scanaill, C.; Dromey, B. Older adults, falls and technologies for independent living: A life space approach. Ageing Soc. 2011, 31, 829-848. [CrossRef]

19. Brodie, M.A.; Coppens, M.J.; Ejupi, A.; Gschwind, Y.J.; Annegarn, J.; Schoene, D.; Wieching, R.; Lord, S.R.; Delbaere, K. Comparison between clinical gait and daily-life gait assessments of fall risk in older people. Geriatr. Gerontol. Int. 2017, 17, 2274-2282. [CrossRef] [PubMed]

20. Scheffer, A.C.; Schuurmans, M.J.; van Dijk, N.; van der Hooft, T.; de Rooij, S.E. Fear of falling: Measurement strategy, prevalence, risk factors and consequences among older persons. Age Ageing 2008, 37, 19-24. [CrossRef] [PubMed]

21. Kempen, G.I.J.M.; Todd, C.J.; van Haastregt, J.C.M.; Zijlstra, G.A.R.; Beyer, N.; Freiberger, E.; Hauer, K.; Piot-Ziegler, C.; Yardley, L. Cross-cultural validation of the Falls Efficacy Scale International (FES-I) in older people: Results from Germany, the Netherlands and the UK were satisfactory. Disabil. Rehabil. 2007, 29, 155-162. [CrossRef] [PubMed]

22. Lach, H.W.; Noimontree, W. Fall prevention among community-dwelling older adults: Current guidelines and older adult responses. J. Gerontol. Nurs. 2018, 44, 21-29. [CrossRef] [PubMed]

23. Sherrington, C.; Michaleff, Z.A.; Fairhall, N.; Paul, S.S.; Tiedemann, A.; Whitney, J.; Cumming, R.G.; Herbert, R.D.; Close, J.C.T.; Lord, S.R. Exercise to prevent falls in older adults: An updated systematic review and meta-analysis. Br. J. Sports Med. 2017, 51, 1749-1757. [CrossRef]

24. Cumming, R.G.; Thomas, M.; Ot, G.D. Home visits by an occupational therapist for assessment and modification of environmental hazards: A randomized trial of falls prevention. J. Am. Geriatr. Soc. 1999, 44, 1397-1402. [CrossRef]

25. LaStayo, P.C.; Ewy, G.A.; Pierotti, D.D.; Johns, R.K.; Lindstedt, S. The positive effects of negative work: Increased muscle strength and decreased fall risk in a frail elderly population. J. Gerontol. 2003, 58, 419-424. [CrossRef]

26. Ejupi, A.; Lord, S.R.; Delbaere, K. New methods for fall risk prediction. Curr. Opin. Clin. Nutr. Metab. Care 2014, 17, 407-411. [CrossRef] 
27. Layton, N.; Clarke, A.; Pennock, J. “Doing with not doing for": A paradigm shift in home care services and what it means for occupational therapy. Aust. Occup. Ther. J. 2014, 61, 11-13. [CrossRef]

28. Balzer, K.; Bremer, M.; Schramm, S.; Lühmann, D.; Raspe, H. Falls prevention for the elderly. GMS Health Technol. Assess. 2012, 8, Doc01. [CrossRef]

29. Cameron, I.D.; Dyer, S.M.; Panagoda, C.E.; Murray, G.R.; Hill, K.D.; Cumming, R.G.; Kerse, N. Interventions for preventing falls in older people in care facilities and hospitals. Cochrane Database Syst. Rev. 2018. [CrossRef] [PubMed]

30. Morello, R.T.; Soh, S.-E.; Behm, K.; Egan, A.; Ayton, D.; Hill, K.; Flicker, L.; Etherton-Beer, C.D.; Arendts, G.; Waldron, N.; et al. Multifactorial falls prevention programmes for older adults presenting to the emergency department with a fall: Systematic review and meta-analysis. Inj. Prev. 2019, 25, 557-564. [CrossRef] [PubMed]

31. Nieto-Riveiro, L.; Groba, B.; Miranda, M.C.; Concheiro, P.; Pazos, A.; Pousada, T.; Pereira, J. Technologies for participatory medicine and health promotion in the elderly population. Med. Baltim. 2018, 97, e10791. [CrossRef] [PubMed]

32. Close, J.; Ellis, M.; Hooper, R.; Glucksman, E.; Jackson, S.; Swift, C. Prevention of falls in the elderly trial (PROFET): A randomised controlled trial. Lancet 1999, 353, 93-97. [CrossRef]

33. Tanaka, M. Multidisciplinary team approach for elderly patients. Geriatr. Gerontol. Int. 2003, 3, 69-72. [CrossRef]

34. Weinstein, M.; Booth, J. Preventing Falls in Older Adults: A Multifactorial Approach. Home Health Care Manag. Pract. 2006, 19, 45-50. [CrossRef]

35. Bleijlevens, M.H.C.; Hendriks, M.R.C.; van Haastregt, J.C.M.; van Rossum, E.; Kempen, G.I.J.M.; Diederiks, J.P.M.; Crebolder, H.F.J.M.; van Eijk, J.T.M. Process factors explaining the ineffectiveness of a multidisciplinary fall prevention programme: A process evaluation. BMC Public Health 2008, 8, 332. [CrossRef]

36. Elliott, S.; Leland, N.E. Occupational therapy fall prevention interventions for community-dwelling older adults: A systematic review. Am. J. Occup. Ther. 2018, 72, 7204190040p1-7204190040p11. [CrossRef]

37. Clemson, L.; Singh, M.F.; Bundy, A.; Cumming, R.G.; Weissel, E.; Munro, J.; Manollaras, K.; Black, D. LiFE Pilot Study: A randomised trial of balance and strength training embedded in daily life activity to reduce falls in older adults. Aust. Occup. Ther. J. 2010, 57, 42-50. [CrossRef]

38. Almeida, T.L.; Alexander, N.B.; Nyquist, L.V.; Montagnini, M.L.; Santos, A.C.S.; Rodrigues, G.H.P.; Negrão, C.E.; Trombetta, I.C.; Wajngarten, M. Minimally supervised multimodal exercise to reduce falls risk in economically and educationally disadvantaged older adults. J. Aging Phys. Act. 2013, 21, 241-259. [CrossRef]

39. Di Monaco, M.; Vallero, F.; De Toma, E.; De Lauso, L.; Tappero, R.; Cavanna, A. A single home visit by an occupational therapist reduces the risk of falling after hip fracture in elderly women: A quasi-randomized controlled trial. J. Rehabil. Med. 2008, 40, 446-450. [CrossRef] [PubMed]

40. Guse, C.E.; Peterson, D.J.; Christiansen, A.L.; Mahoney, J.; Laud, P.; Layde, P.M. Translating a fall prevention intervention into practice: A randomized community trial. Am. J. Public Health 2015, 105, 1475-1481. [CrossRef]

41. World Health Organization. Assistive Technology. Available online: https://www.who.int/health-topics/assistive-technology\# tab=tab_1 (accessed on 3 November 2020).

42. Miskelly, F.G. Assistive technology in elderly care. Age Ageing 2001, 30, 455-458. [CrossRef]

43. Marston, H.R.; Woodbury, A.; Gschwind, Y.J.; Kroll, M.; Fink, D.; Eichberg, S.; Kreiner, K.; Ejupi, A.; Annegarn, J.; de Rosario, H.; et al. The design of a purpose-built exergame for fall prediction and prevention for older people. Eur. Rev. Aging Phys. Act. 2015, 12. [CrossRef] [PubMed]

44. Boulton, E.; Hawley-Hague, H.; Vereijken, B.; Clifford, A.; Guldemond, N.; Pfeiffer, K.; Hall, A.; Chesani, F.; Mellone, S.; Bourke, A.; et al. Developing the FARSEEING Taxonomy of Technologies: Classification and description of technology use (including ICT) in falls prevention studies. J. Biomed. Inform. 2016, 61, 132-140. [CrossRef] [PubMed]

45. Boulton, E.; Hawley-Hague, H.; French, D.P.; Mellone, S.; Zacchi, A.; Clemson, L.; Vereijken, B.; Todd, C. Implementing behaviour change theory and techniques to increase physical activity and prevent functional decline among adults aged 61-70: The PreventIT project. Prog. Cardiovasc. Dis. 2019, 62, 147-156. [CrossRef]

46. Arksey, H.; O’Malley, L. Scoping studies: Towards a methodological framework. Int. J. Soc. Res. Methodol. 2005, 8, 19-32. [CrossRef]

47. Tricco, A.C.; Lillie, E.; Zarin, W.; O’Brien, K.K.; Colquhoun, H.; Levac, D.; Moher, D.; Peters, M.D.J.; Horsley, T.; Weeks, L.; et al. PRISMA extension for scoping reviews (PRISMA-ScR): Checklist and explanation. Ann. Intern. Med. 2018, 169, 467. [CrossRef]

48. Moher, D.; Liberati, A.; Tetzlaff, J.; Altman, D.G. Preferred reporting items for systematic reviews and meta-analyses: The PRISMA statement. PLoS Med. 2009, 6, e1000097. [CrossRef]

49. Biblioteca Virtual de Salud España. 1998. Available online: https://bvsalud.isciii.es/ (accessed on 1 November 2020).

50. CINAHL: Cumulative Index to Nursing and Allied Health Literature. 2003. Available online: http://www.bugalicia.org/ recursos/ebsco/cinahl/ (accessed on 1 November 2020).

51. Biblioteca Cochrane. 2000. Available online: https://www.cochranelibrary.com/es/ (accessed on 1 November 2020).

52. OTseeker: Occupational Therapy Sistematic Evaluation of Evidence. 2003. Available online: http://www.otseeker.com/ (accessed on 1 November 2020).

53. PubMed.gov. 1996. Available online: https://pubmed.ncbi.nlm.nih.gov/ (accessed on 1 November 2020).

54. Scopus. 2004. Available online: https:/ / scopus.com (accessed on 1 November 2020).

55. Web of Science. 2016. Available online: https://webofknowledge.com/WOS (accessed on 1 November 2020). 
56. Mendeley Reference Manager. 2009. Available online: https://www.mendeley.com/reference-management/reference-manager (accessed on 1 November 2020).

57. Braun, V.; Clarke, V. Using thematic analysis in psychology. Qual. Res. Psychol. 2005, 3, 77-101. [CrossRef]

58. Chase, C.A.; Mann, K.; Wasek, S.; Arbesman, M. Systematic review of the effect of home modification and fall prevention programs on falls and the performance of community-dwelling older adults. Am. J. Occup. Ther. 2012, 66, 284-291. [CrossRef] [PubMed]

59. Horowitz, B.P.; Nochajski, S.M.; Schweitzer, J.A. Occupational therapy community practice and home assessments: Use of the home safety self-assessment tool (HSSAT) to support aging in place. Occup. Ther. Health Care 2013, 27, 216-227. [CrossRef] [PubMed]

60. Charness, N. Utilizing technology to improve older adult health. Occup. Ther. Health Care 2014, 28, 21-30. [CrossRef] [PubMed]

61. Arthanat, S.; Wilcox, J.; Macuch, M. Profiles and predictors of smart home technology adoption by older adults. OTJR Occup. Particip. Health 2019, 39, 247-256. [CrossRef] [PubMed]

62. Stewart, L.S.P.; McKinstry, B. Fear of falling and the use of telecare by older people. Br. J. Occup. Ther. 2012, 75, 304-312. [CrossRef]

63. Glännfjord, F.; Hemmingsson, H.; Larsson Ranada, Å. Elderly people's perceptions of using Wii sports bowling-A qualitative study. Scand. J. Occup. Ther. 2017, 24, 329-338. [CrossRef]

64. Hamm, J.; Money, A.; Atwal, A. Fall prevention self-assessments via mobile 3D visualization technologies: Community dwelling older adults' perceptions of opportunities and challenges. JMIR Hum. Factors 2017, 4, e15. [CrossRef]

65. Lemmens, R.; Gielen, C.; Spooren, A. Obstacle: A tool to assess the home environment designed for all. Stud. Health Technol. Inform. 2017, 242, 168-174.

66. Hamm, J.; Money, A.G.; Atwal, A. Enabling older adults to carry out paperless falls-risk self-assessments using guidetomeasure3D: A mixed methods study. J. Biomed. Inform. 2019, 92, 103135. [CrossRef]

67. Money, A.G.; Atwal, A.; Boyce, E.; Gaber, S.; Windeatt, S.; Alexandrou, K. Falls sensei: A serious 3D exploration game to enable the detection of extrinsic home fall hazards for older adults. BMC Med. Inform. Decis. Mak. 2019, 19, 85. [CrossRef]

68. Khaled, A.B.H.; Khalfallah, A.; Bouhlel, M.S. Fall prevention exergame using occupational therapy based on kinect. In Smart Innovation, Systems and Technologies; Springer Science and Business Media Deutschland GmbH: Berlin, Germany, 2020; Volume 146, pp. 479-493.

69. Bianco, M.; Pedell, S.; Renda, G. Augmented reality and home modifications. In Proceedings of the 28th Australian Conference on Computer-Human Interaction-OzCHI 2016, Launceston, Australia, 29 November-2 December 2016; ACM Press: New York, NY, USA, 2016; pp. 499-507. [CrossRef]

70. Drobics, M.; Lord, S.R.; Gschwind, Y.J.; Delbaere, K.; Aal, K.; Wieching, R.; de Rosario, H.; Marston, H.R.; Woodbury, A.; Kroll, M.; et al. ICT-based system to predict and prevent falls (iStoppFalls): Results from an international multicenter randomized controlled trial. Eur. Rev. Aging Phys. Act. 2015, 12, 10. [CrossRef]

71. Özsungur, F. A research on the effects of successful aging on the acceptance and use of technology of the elderly. Assist. Technol. 2019, 18, 1-14. [CrossRef] [PubMed]

72. e Silva, J.S.; Gonçalves, R.; Branco, F.; Pereira, A.; Au-Yong-Oliveira, M.; Martins, J. Accessible software development: A conceptual model proposal. Univers. Access Inf. Soc. 2019, 18, 703-716. [CrossRef]

73. Design for All Foundations. Available online: http:// designforall.org/index.php (accessed on 5 November 2020).

74. Oxford Institute of Population Ageing. Bridging the Digital Divide amongst Older Adults. Available online: https://www. ageing.ox.ac.uk/blog/digital-divide (accessed on 5 November 2020).

75. World Health Organization. Ageing: Healthy Ageing and Functional Ability. Available online: https://www.who.int/ westernpacific/news/q-a-detail/ageing-healthy-ageing-and-functional-ability (accessed on 5 November 2020).

76. Oxford Martin School. Life Expectancy-Our World in Data. Available online: https://ourworldindata.org/life-expectancy (accessed on 5 November 2020).

77. World Health Organization. Life Expectancy at Age 60 (Years). Available online: https:/ /www.who.int/publications/data/gho/ data/indicators/indicator-details/GHO/life-expectancy-at-age-60-(years) (accessed on 5 November 2020).

78. Brandis, S.J.; Tuite, A.T. Falls prevention: Partnering occupational therapy and general practitioners. Aust. Health Rev. 2001, 24, 37-42. [CrossRef] [PubMed]

79. Wiles, J.L.; Leibing, A.; Guberman, N.; Reeve, J.; Allen, R.E.S. The Meaning of "Aging in Place" to Older People. Gerontologist 2012, 52, 357-366. [CrossRef] [PubMed]

80. National Institute on Aging. Aging in Place: Growing Older at Home. Available online: https://www.nia.nih.gov/health/agingplace-growing-older-home\#planning (accessed on 5 November 2020).

81. Nagayama, H.; Tomori, K.; Ohno, K.; Takahashi, K.; Yamauchi, K. Cost-effectiveness of Occupational Therapy in Older People: Systematic Review of Randomized Controlled Trials. Occup. Ther. Int. 2016, 23, 103-120. [CrossRef]

82. Walker, J.E.; Howland, J. Falls and fear of falling among elderly persons living in the community: Occupational therapy interventions. Am. J. Occup. Ther. 1991, 45, 119-122. [CrossRef]

83. Somerville, E.; Smallfield, S.; Stark, S.; Seibert, C.; Arbesman, M.; Lieberman, D. Occupational therapy home modification assessment and intervention. Am. J. Occup. Ther. 2016, 70, 7005395010p1-7005395010p3. [CrossRef]

84. Lord, S.R.; Menz, H.B.; Sherrington, C. Home environment risk factors for falls in older people and the efficacy of home modifications. Age Ageing 2006, 35, 55-59. [CrossRef] 
85. Cumming, R.G.; Thomas, M.; Szonyi, G.; Frampton, G.; Salkeld, G.; Clemson, L. Adherence to occupational therapist recommendations for home modifications for falls prevention. Am. J. Occup. Ther. 2001, 55, 641-648. [CrossRef]

86. Mirelman, A.; Rochester, L.; Maidan, I.; Del Din, S.; Alcock, L.; Nieuwhof, F.; Rikkert, M.O.; Bloem, B.R.; Pelosin, E.; Avanzino, L.; et al. Addition of a non-immersive virtual reality component to treadmill training to reduce fall risk in older adults (V-TIME): A randomised controlled trial. Lancet 2016, 388, 1170-1182. [CrossRef]

87. Vaziri, D.D.; Aal, K.; Gschwind, Y.J.; Delbaere, K.; Weibert, A.; Annegarn, J.; de Rosario, H.; Wieching, R.; Randall, D.; Wulf, V. Analysis of effects and usage indicators for a ICT-based fall prevention system in community dwelling older adults. Int. J. Hum. Comput. Stud. 2017, 106, 10-25. [CrossRef] 